\title{
DNA Functionality with Photoswitchable Hydrazone Cytidine
}

\author{
Song Mao, ${ }^{1,2}$ Zhihua Chang $^{1,2}$, Ya Ying Zheng ${ }^{1,2}$, Alexander Shekhtman ${ }^{1}$ and Jia \\ Sheng ${ }^{1,2, *}$ \\ ${ }^{1}$ Department of Chemistry and ${ }^{2}$ The RNA Institute, University at Albany, State \\ University of New York, 1400 Washington Ave. Albany, NY, 12222, USA. \\ *Email: jsheng@albany.edu
}

\begin{abstract}
A new family of hydrazone modified cytidine phosphoramidite building block was synthesized and incorporated into DNA oligonucleotides to construct photoswitchable DNA strands. The $E-Z$ isomerization triggered by the irradiation of blue light with a wavelength of $450 \mathrm{~nm}$ was investigated and confirmed by ${ }^{1} \mathrm{H}$ NMR and HPLC in the contexts of both nucleoside and DNA oligonucleotide. The light activated $Z$ form isomer of this hydrazone-cytidine with a six-member intramolecular hydrogen bond was found to inhibit DNA synthesis in the primer extension model by using Bst DNA polymerase. In addition, the hydrazone modification caused the misincorporation of dATP together with dGTP into the growing DNA strand with similar selectivity, highlighting the potential $\mathrm{G}$ to $\mathrm{A}$ mutation. This work provides a novel functional DNA building block and an additional molecular tool that have potential chemical biology and bio-medicinal applications to control DNA synthesis and DNA-enzyme interactions using cell friendly blue light irradiation.
\end{abstract}

Deoxyribonucleic acid (DNA) carries the genetic information of living organisms and plays critical roles in numerous normal and diseased cellular functions and processes. In addition, it has tremendous application potentials in nanotechnology and advanced material science. ${ }^{1}$ Since the elucidation of the double stranded helical structure of DNA, ${ }^{2,3}$ immense work have been developed and utilized in the study of nucleic acid structure diversity and the impacts of the structural regulations on biological processes in the past few decades. ${ }^{4-6}$ Other structures such as hairpin, ${ }^{7}$ triplexes, ${ }^{8}$ Holliday junction ${ }^{9-11}$ and G-quadruplexes ${ }^{12}$ have been demonstrated as natural approaches to regulate DNA functions. In addition, a verity of external stimuli, including temperature, ${ }^{13,14} \mathrm{pH},{ }^{15,16}$ small molecule ligands, ${ }^{17-19}$ metal ions ${ }^{20-26}$ and light, ${ }^{27-32}$ have been extensively developed to control DNA synthesis and structures and thus to impact a wide range of biological processes such as DNA replication, 
RNA transcription, as well as the overall gene expression \& repair. Among all the existing stimuli and triggers for chemical and biological manipulations of DNA, light seems to be an ideal and very attractive candidate because it is noninvasive and has a high level of spatial and temporal resolution for in vivo application.

In order to achieve the photoregulation of oligonucleotides, a wide range of photoswitches, a class of compounds that could undergo light-controlled reversible chemical conversions, have been incorporated into DNA and RNA oligonucleotides to control their structures and biological functions, ${ }^{31,32}$ owing to the well-developed nucleic acid solid phase synthesis in the past decades. ${ }^{33-36}$ Among them, azobenzens, ${ }^{37}$ stilbenes, ${ }^{30}$ hemithioindigos and their derivatives ${ }^{38}$ belong to the cis-trans isomerization category, while spiropyrans, diarylethenes, thiophenefulgides and their derivatives ${ }^{39}$ have reversible open-and-closed states. Another regularly used DNA control approach is to use light sensitive caging groups to block the normal DNA structures and functions in some key positions and subsequently to release the inhibitory cages upon light irradiations for DNA recovery. ${ }^{29,40-42}$ By taking advantage of the high modularity and synthetic accessibility of oligonucleotides, these photoregulatory functionalities could be installed or modified on nucleobases, sugar moiety and phosphate backbone of DNA. Despite the tremendous progress in DNA functionalities, however, the application of the photoregulation strategy is often limited by the use of UV light, which is toxic and damaging to DNA and the whole cells. $^{43,44}$ In this content, the development of more novel photocontrollable chromophores that could use nonhazardous visible lights to trigger the photoconversions on DNA has recently emerged as a very important challenges.

Hydrazones is a kind of well-developed chromophore that can undergo $E / Z$ isomerizations in response to photochemical or thermal stimuli with high conversion yields to both states. ${ }^{45-53}$ They have been widely used in medicinal ${ }^{54}$ and adaptive materials developments. ${ }^{55-57}$ Particularly, the pyridyl hydrazone unit, initially developed by Lehn and coworkers, ${ }^{58}$ has been attracted great attentions due to the fact that 2-pyridyl ring can form a six-membered intramolecular hydrogen bond with the amide N-H of the hydrazone in the $Z$ form upon irradiation with blue light with the wavelength of $\sim 450 \mathrm{~nm} .{ }^{59}$ Inspired by this property, we designed the 2-pyridyl hydrazone on the $\mathrm{N} 4$ position of cytidine and incorporated it into DNA oligonucleotides. We hypothesize that the formation of intramolecular H-bond with 
pyridine ring upon blue light irradiation could cause steric hindrance with the carbonyl group of guanosine and perturb the Watson-Crick $C: G$ base pair (Figure 1A). Before light exposure, this hydrazone modified nucleoside keeps the stable $E$ form and retains the normal Watson-Crick G:C pairing with three hydrogen bonds. After light exposure, the 2-pyridyl hydrazone switches to the $Z$ form and disrupts the base pair by the six-membered intramolecular hydrogen bonding. This $E-Z$ conversion process can be controlled by light and heat. In addition, we also demonstrated that this light controlling mechanism can be used to affect DNA-protein interactions and further regulate DNA synthesis during gene replication (Figure 1B).

A

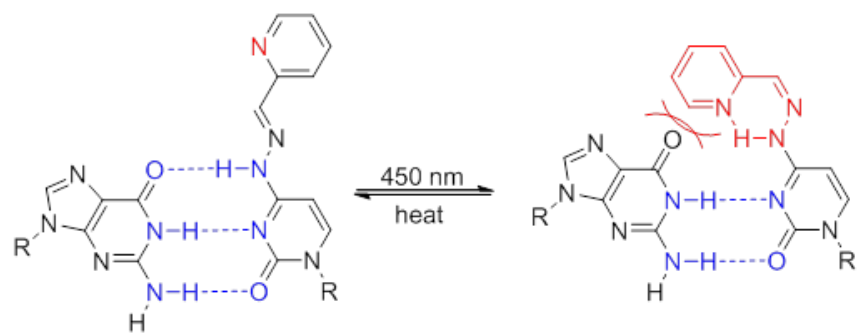

B
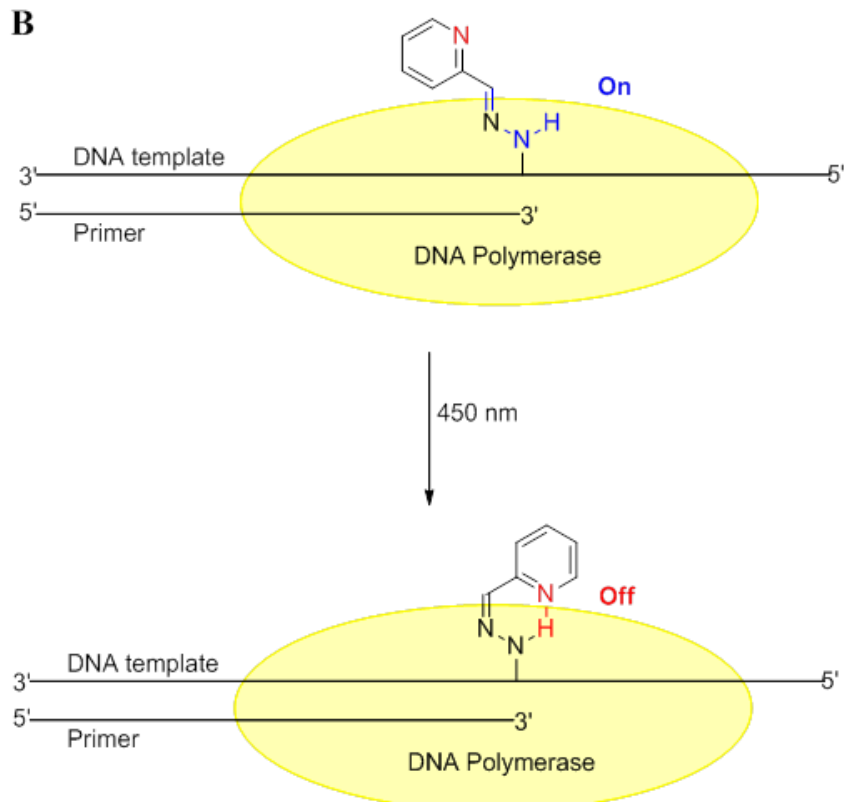

Figure 1. Schematic illustration of our photoswitchable hydrazone-DNA system and its application. (A) Light control of G:C base pair. (B) Regulation of DNA-Protein interaction and DNA synthesis.

We started the synthesis of target photoswitchable hydrazone modified cytidine phosphoramidite from commercially available deoxyuridine 1 (Scheme 1). Silylation of the 5'- and 3'-hydroxy groups with di-tert-butylsilyl ditriflate gave silylated compound 2, which was converted to compound $\mathbf{3}$ via Appel reaction in the 
presence of $\mathrm{PPh}_{3}$ and $\mathrm{CH}_{2} \mathrm{Cl}_{2} / \mathrm{CCl}_{4}$. The coupling of pyridine-2-aldehyde hydrazone 4 with chloro- 4 in the absence of any base provided the hydrazone modified nucleoside 5, which was protected with trifluoroacetyl group at N4 position to afford compound 6. Subsequently, this compound was desilylated by using hydrogen fluoride in pyridine $(\mathrm{HF} \bullet \mathrm{Py})$, followed by the tritylation step with trityl chloride $(\mathrm{DMTrCl})$ at 5 'position to generate the key intermediate $\mathbf{8}$, which was converted into the final photoswitchable hydrazone phosphoramidite 9 through a regular phosphitylation reaction for the solid-phase synthesis. This building block 9 was unstable in light and was therefore purified by quickly flushing over an aluminum foil covered $\mathrm{SiO}_{2}$ column, dissolved in acetonitrile under an argon atmosphere, and immediately used in DNA synthesizer. This hydrazone phosphoramidite building block was well compatible with the regular solid-phase synthesis conditions, including trichloroacetic acid (TCA) and oxidative iodine treatments. The modified DNA oligonucleotides were also found to be fully deprotected and stable under basic cleavage from solidphase beads. As a demonstration, various strands of DNA oligonucleotides containing this hydrazone chromophore were synthesized, purified and confirmed by Orbitrap MS, as shown in Table S1.

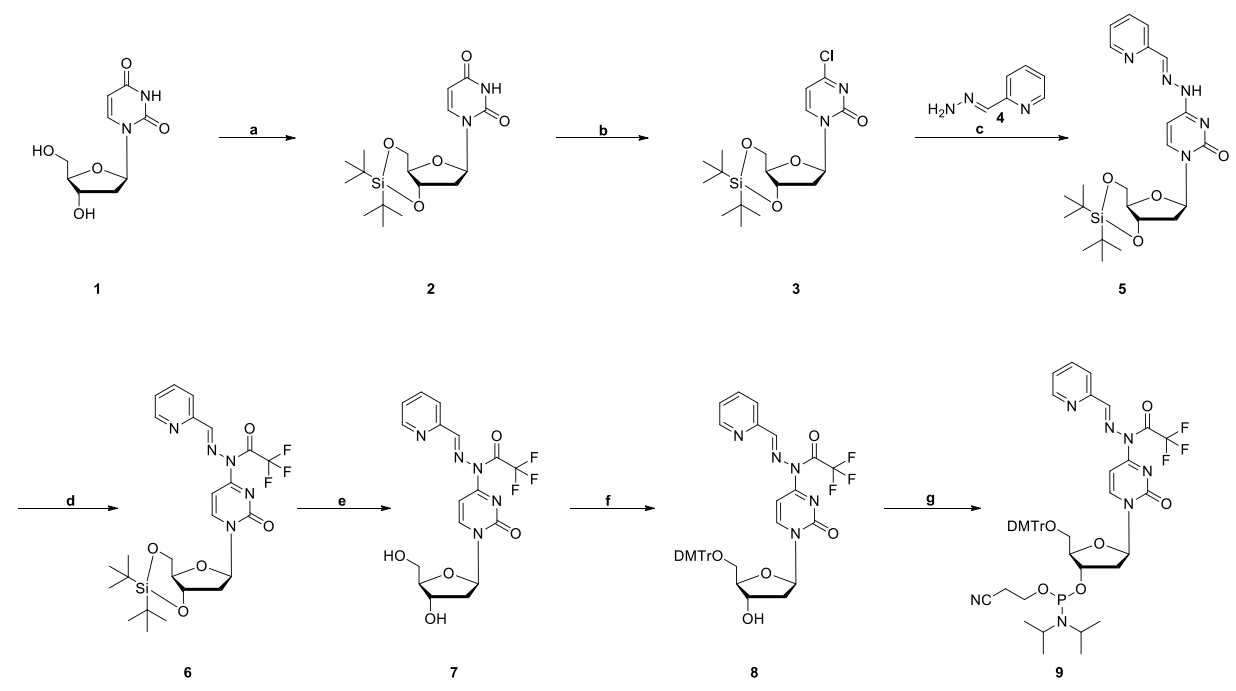

Scheme 1. Synthesis of photoswitchable hydrazon-deoxycytidine phosphoramidite 9. Reagents and conditions: (a) ( $t$-Bu $)_{2} \mathrm{Si}(\mathrm{OTf})_{2}$, imidazole, DMF; (b) $\mathrm{PPh}_{3}$, $\mathrm{CH}_{2} \mathrm{Cl}_{2} / \mathrm{CCl}_{4}$; (c) pyridine-2-aldehyde hydrazone 4, DMF; (d) TFAA, DCM; (e) $\mathrm{HF} \bullet \mathrm{Py}, \mathrm{THF}$; (f) DMTrCl, Py; (g) $\left(i-\mathrm{Pr}_{2} \mathrm{~N}\right)_{2} \mathrm{P}(\mathrm{Cl}) \mathrm{OCH}_{2} \mathrm{CH}_{2} \mathrm{CN}, \quad(i-\mathrm{Pr})_{2} \mathrm{NEt}, \quad 1-$ methylimidazole, $\mathrm{CH}_{2} \mathrm{Cl}_{2}$. 
We first demonstrated the photoswitchable $E / Z$ isomerization of this hydrazone cytidine using a solution of $85 \mathrm{mM}$ compound $\mathbf{5 - E}$ in $\mathrm{CDCl}_{3}$ irradiated with a $450 \mathrm{~nm}$ blue light and monitoring the conversion by ${ }^{1} \mathrm{H}$ NMR. As the spectra shown in Figure 2A, after 2 hours, $89 \%$ of isomer $\mathbf{5 - Z}$ with a strong H-bond between imino proton of the hydrozone and the nitrogen of the pyridine at $14.58 \mathrm{ppm}$ was obtained, which is consistent with our TLC study (Figure S29). Meanwhile, the characteristic imine proton peak of the $5-\boldsymbol{E}$ (peak 5) with chemical shift of $8.70 \mathrm{ppm}$ gradually shifted to $7.35 \mathrm{ppm}$ in $5-Z$. The time-course ratios of $Z: E$ at $10 \mathrm{~min}, 30 \mathrm{~min}$ and $60 \mathrm{~min}$ were also monitored respectively. We further investigated the back isomerization from $\mathbf{5 - Z}$ to $\mathbf{5 - E}$ under different temperatures. As a result, heating the samples at $37^{\circ} \mathrm{C}$ under dark for $24 \mathrm{~h}$ only gave 47:53 ratio of $E: Z$ (Figure S30), while a maximum ratio of $67: 33$ was observed after heating the solution at $60{ }^{\circ} \mathrm{C}$ for $48 \mathrm{~h}$ (Figure S31), indicating that this six member intramolecular hydrogen bonding structure is quite stable once formed by blue light irradiation.

We next examined whether similar hydrogen bonded $Z$ form isomer can be formed in DNA contexts. As the example, a short 6-mer DNA ON6 (Table S1) 5'ATC*ACG-3' with the hydrazone modification in the middle position was evaluated by analytical HPLC and ${ }^{1} \mathrm{H}$ NMR. In the initial state, a mixture of $E: Z$ isomers with the ratio of 91:9 was determined by analytical HPLC (Figure 2B). Upon $2 \mathrm{~h}$ irradiation with a $450 \mathrm{~nm}$ blue light, over $99 \%$ of $Z$ isomer was ideally achieved. And the ${ }^{1} \mathrm{H}$ NMR spectrum (Figure 2C) in the aqueous solution, $10 \mathrm{mM}$ sodium phosphate buffer $(\mathrm{pH}=6.5)$ with $50 \mathrm{mM} \mathrm{NaCl}$ containing $10 \% \mathrm{D}_{2} \mathrm{O}$, showed the hydrazone $\mathrm{N}-\mathrm{H}$ imino proton signal of $Z$ isomer at $14.13 \mathrm{ppm}$, indicating the intramolecular H-bond between the imino proton of the hydrozone and the nitrogen of the pyridine can also form and is more dominant in the DNA oligonucleotide than in the nucleoside form. In addition, the hydrogen bonded $Z$ form isomer in DNA is quite stable. No isomerization of $Z$ back to $E$ was observed from the analytical HPLC profiles after heating the solution at $37^{\circ} \mathrm{C}$ for one hour under dark condition (Figure S32-S33). 


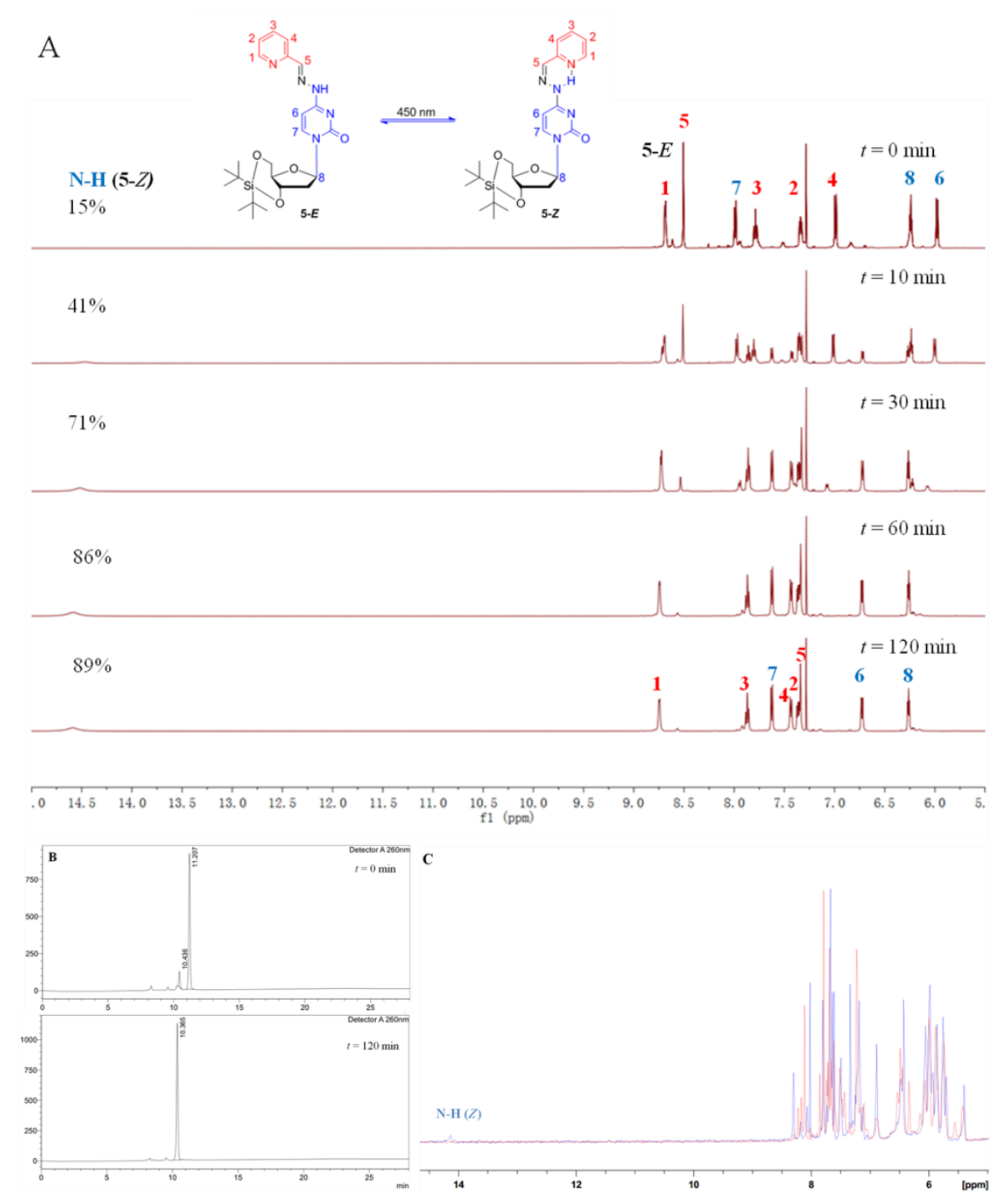

Figure 2. (A) $500 \mathrm{MHz}{ }^{1} \mathrm{H}$ NMR spectra of a $85 \mathrm{mM}$ solution of $\mathbf{5 - E}$ under $450 \mathrm{~nm}$ blue light irradiation for different time. (B) Analytical HPLC spectra of ON6 5'ATC*ACG-3' before and after a $450 \mathrm{~nm}$ blue light irradiation, with the retention time of 11.2 and 10.4 mins respectively. (C) $600 \mathrm{MHz}{ }^{1} \mathrm{H}$ NMR spectra of a $100 \mu \mathrm{M}$ of ON6 5'-ATC*ACG-3 in $10 \mathrm{mM}$ sodium phosphate buffer $(\mathrm{pH}=6.5)$ with $50 \mathrm{mM}$ $\mathrm{NaCl}$ containing $10 \% \mathrm{D}_{2} \mathrm{O}$ before (red) and after (blue) the blue light irradiation. Water gate pulse sequence was used for water suppression during ${ }^{1} \mathrm{H}$ NMR experiment ${ }^{60}$.

DNA replication occurs in all living organisms and acts as the most essential part for biological inheritance. Chemical modifications on DNA polymerase ${ }^{61}$ and DNA nucleotides ${ }^{26,62,63}$ have been developed for controlling DNA synthesis. Having demonstrated the intramolecular H-bond $Z$ isomer can be formed in both nucleoside and DNA oligonucleotides, we further set out to investigate the potential impacts of 
this hydrazone modification on DNA synthesis by conducting the template directed primer extension reactions as the DNA replication model. As shown in Figure 3, the 5 '-end of DNA primer was labeled with fluorescent FAM group and the 27nt-long modified DNA (ON5, Table S1) was designed as the template with hydrazone on the starting site of the replication reaction, which represents a direct and effective way to explore the enzymatic compatibility and coding property of the modified residue in this biological process. The yields and fidelity of DNA synthesis with different base pairing substrates in the presence of two different example DNA polymerases, the Bacillus stearothermophilus (Bst) DNA polymerase ${ }^{64,65}$ and DreamTaq DNA polymerase, ${ }^{66,67}$ were quantitated by fluorescence gel images with single-nucleotide resolution.

\begin{tabular}{|c|c|}
\hline \multicolumn{2}{|c|}{ Primer extension reactions } \\
\hline $\begin{array}{l}\text { DNA primer } \\
\text { DNA temnlate }\end{array}$ & $\begin{array}{cc}\text { 5'-FAM- CCATGTCCTCATAGC } \\
\text { 3'-CTTCCGACGGTACAGGAGTATCGC *AAG-5' }\end{array}$ \\
\hline DNA temprate & \\
\hline
\end{tabular}

Figure 3. Primer extension reaction.

When the Bst DNA polymerase was used in this system, the primer extension reaction completed with high yield of $27 \mathrm{nt}$-full length product in the presence of all the natural dNTPs with native template (lane Nat in Figure 4A), while the template with hydrazone modification before light exposure can also give the full-length product with moderate yield and some uncompleted short DNA products (lane $\mathrm{M}$ in Figure 4A). Strikingly, after irradiating the template with a $450 \mathrm{~nm}$ blue light for 2 hours, the DNA synthesis was fully shut down without the formation of any fulllength product (lane M-hv in Figure 4A), indicting the resulting intramolecular $Z$ isomer dramatically inhibited the polymerase activity in this DNA synthesis. Next, the DreamTaq DNA polymerase was examined in the same system. As expected, the fulllength product was obtained in similar yield as the Bst case in the absence of light stimulus (lane $\mathrm{M}$ in Figure 4B), although some over synthesized DNA band was observed, similar as in the native conditions (lane Nat). After the blue light irradiation, although the overall yield of full-length product was significantly decreased, in comparison to the Bst case, a much lower level of synthesis impedance of this isomerization was detected (lane M-hv in Figure 4B). It is known that the DreamTaq DNA polymerase has higher flexibility and substrate compatibility, which might 
result in lower replication fidelity for target DNA synthesis. Indeed, we further investigated the single nucleotide incorporation under these conditions and found that the hydrazone modification dramatically decreased the dGTP incorporation efficiency and increased the dATP incorporation to the same level as dGTP during the first nucleotide synthesis in the presence of either DNA polymerase (lanes A and G in Figure 5 and S35), implying a $G$ to A mutation in the synthesized DNA. This process is not associated with the light irradiation (Figure 5B and 5C, S34B and S34C).

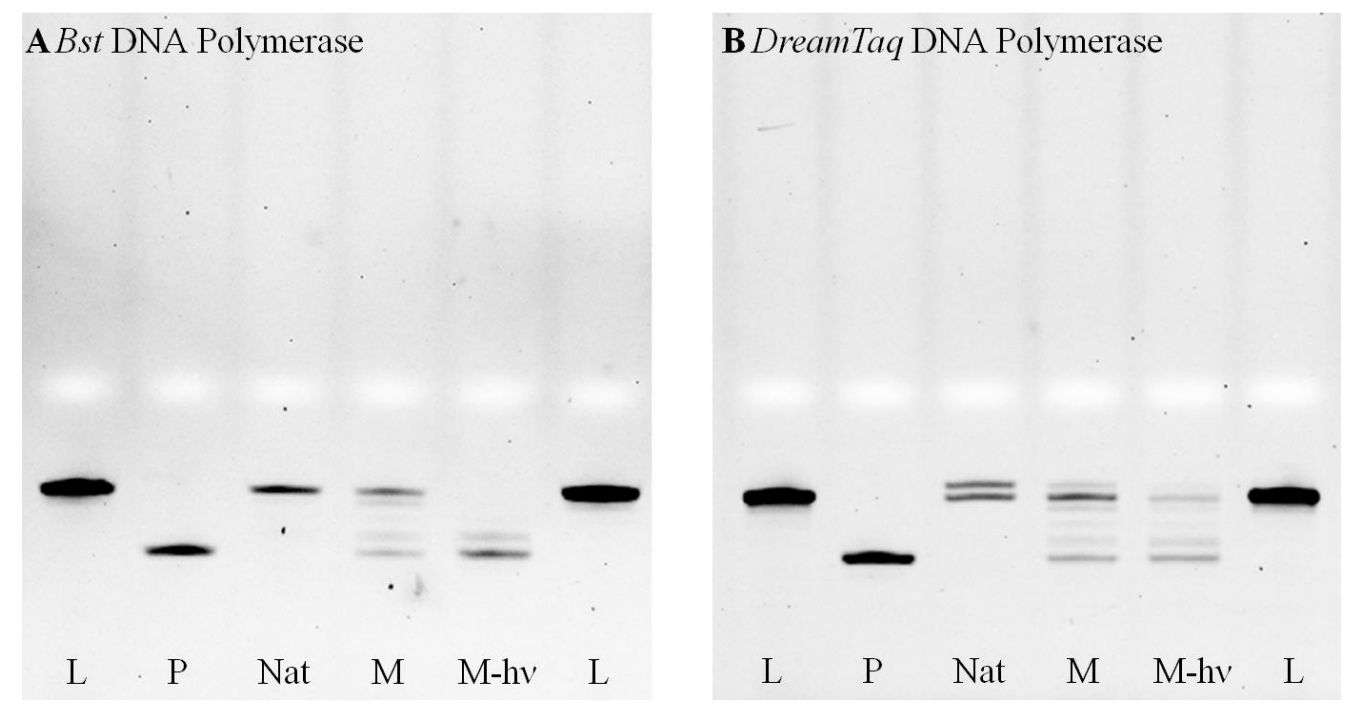

Figure 4. Fluorescent gel images of standing-start primer extension reactions for Bst (A) and DreamTaq (B) DNA polymerase using native and hydrazone-modified DNA templates. Lanes: L, reference DNA 27-mer ladder; P, primer; Nat, natural template with all four dNTPs; M, hydrazone-modified template before blue light irradiation with all four dNTPs; M-hv, hydrazone-modified template after $2 \mathrm{~h}$ blue light irradiation with all four dNTPs.

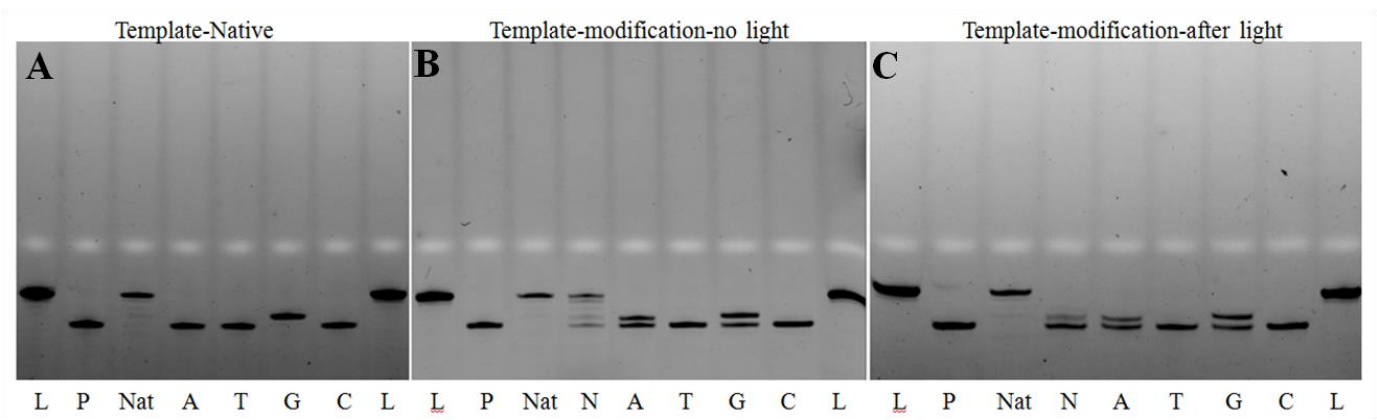

Figure 5. Fluorescent gel images of primer extension reactions with Bst DNA polymerase using native (A), hydrazone-modified DNA templates before (B) and after (C) blue light irradiation. Lanes: L, reference DNA 27-mer ladder; P, primer; Nat, natural template with all four dNTPs as positive controls in each gel; A, T, G, 
and $\mathrm{C}$, reactions in the presence of the respective dNTP only; $\mathrm{N}$, reactions in the presence of all the four dNTPs.

In conclusion, the hydrazone modified cytidine phosphoramidite building block was synthesized and successfully incorporated into the DNA oligonucleotides by using solid-phase to construct photoswitchable DNA strands. The $E-Z$ isomerization triggered by the irradiation of blue light with a wavelength of $450 \mathrm{~nm}$ was investigated and confirmed by ${ }^{1} \mathrm{H}$ NMR and HPLC in the contexts of both nucleoside and DNA oligonucleotide. The light activated $Z$ form isomer of this hydrazone-cytidine with a six-member intramolecular hydrogen bond was found to inhibit DNA synthesis in our primer extension model in the presence of Bst DNA polymerase. When using the DreamTaq DNA polymerase, this photoswitchable hydrazone modification partially impeded the DNA synthesis to a lower extent than the $B s t$ one. In addition, this hydrazone modified cytidine in the template could cause the misincorporation of dATP together with dGTP into the growing DNA strand with similar selectivity. This work provides a novel functional DNA building block and an additional molecular tool that can be exploited for the control of DNA synthesis and DNA-enzyme interactions using cell friendly blue light irradiation.

\section{ASSOCIATED CONTENT}

\section{Supporting Information}

The Supporting Information is available free of charge on the ACS Publications website.

Experimental procedures, spectral data, gel images of primer extension reactions.

\section{AUTHOR INFORMATION}

\section{Corresponding Author}

*Email: jsheng@albany.edu

\section{Notes}

The authors declare no competing financial interest.

\section{ACKNOWLEDGMENTS}

We thank NSF (CHE-1845486, MCB-1715234 and CHE-1726724) and University at Albany, State University of New York for the financial support.

\section{REFERENCES}


(1) Keller, A.; Linko, V. Challenges and Perspectives of DNA Nanostructures in Biomedicine. Angew. Chem. Int. Ed. 2020, 59, 15818-15833.

(2) Avery, O. T.; Macleod, C. M.; McCarty, M. Studies on the Chemical Nature of the Substance Inducing Transformation of Pneumococcal Types : Induction of Transformation by a Desoxyribonucleic Acid Fraction Isolated from Pneumococcus Type Iii. J. Exp. Med. 1944, 79, 137-158.

(3) Watson, J. D.; Crick, F. H. Molecular structure of nucleic acids; a structure for deoxyribose nucleic acid. Nature 1953, 171, 737-738.

(4) Goldman, N.; Bertone, P.; Chen, S.; Dessimoz, C.; LeProust, E. M.; Sipos, B.; Birney, E. Towards practical, high-capacity, low-maintenance information storage in synthesized DNA. Nature 2013, 494, 77-80.

(5) Jones, M. R.; Seeman, N. C.; Mirkin, C. A. Nanomaterials. Programmable materials and the nature of the DNA bond. Science 2015, 347, 1260901.

(6) Ledford, H. CRISPR: gene editing is just the beginning. Nature 2016, 531, 156-159.

(7) Lin, C. T.; Lin, W. H.; Lyu, Y. L.; Whang-Peng, J. Inverted repeats as genetic elements for promoting DNA inverted duplication: implications in gene amplification. Nucleic Acids Res. 2001, 29, 3529-3538.

(8) Hu, Y.; Cecconello, A.; Idili, A.; Ricci, F.; Willner, I. Triplex DNA Nanostructures: From Basic Properties to Applications. Angew. Chem. Int. Ed. 2017, 56, 15210-15233.

(9) Chandrasekaran, A. R.; Vilcapoma, J.; Dey, P.; Wong-Deyrup, S. W.; Dey, B. K.; Halvorsen, K. Exceptional Nuclease Resistance of Paranemic Crossover (PX) DNA and Crossover-Dependent Biostability of DNA Motifs. J. Am. Chem. Soc. 2020, 142, 6814-6821.

(10) Holliday, R. A mechanism for gene conversion in fungi. Genet. Res. 1964, 5, 282-304.

(11) Shen, Z.; Yan, H.; Wang, T.; Seeman, N. C. Paranemic crossover DNA: a generalized Holliday structure with applications in nanotechnology. J. Am. Chem. Soc. 2004, 126, 16661674.

(12) Varshney, D.; Spiegel, J.; Zyner, K.; Tannahill, D.; Balasubramanian, S. The regulation and functions of DNA and RNA G-quadruplexes. Nat. Rew. Mol. Cell Biol. 2020, 21, 459474.

(13) Gerling, T.; Wagenbauer, K. F.; Neuner, A. M.; Dietz, H. Dynamic DNA devices and assemblies formed by shape-complementary, non-base pairing 3D components. Science 2015, 347, 1446-1452.

(14) Hamada, S.; Yancey, K. G.; Pardo, Y.; Gan, M. Z.; Vanatta, M.; An, D.; Hu, Y.; Derrien, T. L.; Ruiz, R.; Liu, P. F.; Sabin, J.; Luo, D. Dynamic DNA material with emergent locomotion behavior powered by artificial metabolism. Sci. Robot. 2019, 4, eaaw3512.

(15) Debnath, M.; Fatma, K.; Dash, J. Chemical Regulation of DNA i-Motifs for Nanobiotechnology and Therapeutics. Angew. Chem. Int. Ed. 2019, 58, 2942-2957.

(16) Zeraati, M.; Langley, D. B.; Schofield, P.; Moye, A. L.; Rouet, R.; Hughes, W. E.; Bryan, T. M.; Dinger, M. E.; Christ, D. I-motif DNA structures are formed in the nuclei of human cells. Nat. Chem. 2018, 10, 631-637.

(17) Chen, H.; Zhang, H.; Pan, J.; Cha, T. G.; Li, S.; Andreasson, J.; Choi, J. H. Dynamic and Progressive Control of DNA Origami Conformation by Modulating DNA Helicity with Chemical Adducts. ACS Nano 2016, 10, 4989-4996.

(18) Ruscito, A.; DeRosa, M. C. Small-Molecule Binding Aptamers: Selection Strategies, Characterization, and Applications. Front. Chem. 2016, 4, 14.

(19) Sheng, J.; Gan, J.; Huang, Z. Structure-based DNA-targeting strategies with small molecule ligands for drug discovery. Med. Res. Rev. 2013, 33, 1119-1173.

(20) Liu, H.; Shen, F.; Haruehanroengra, P.; Yao, Q.; Cheng, Y.; Chen, Y.; Yang, C.; Zhang, J.; Wu, B.; Luo, Q.; Cui, R.; Li, J.; Ma, J.; Sheng, J.; Gan, J. A DNA Structure Containing Ag(I) -Mediated G:G and C:C Base Pairs. Angew. Chem. Int. Ed. 2017, 56, 9430-9434.

(21) Mistry, L.; El-Zubir, O.; Dura, G.; Clegg, W.; Waddell, P. G.; Pope, T.; Hofer, W. A.; Wright, N. G.; Horrocks, B. R.; Houlton, A. Addressing the properties of "Metallo-DNA" with a $\mathrm{Ag}(\mathrm{i})$-mediated supramolecular duplex. Chem. Sci. 2019, 10, 3186-3195.

(22) Ono, A.; Torigoe, H.; Tanaka, Y.; Okamoto, I. Binding of metal ions by pyrimidine base pairs in DNA duplexes. Chem. Soc. Rev. 2011, 40, 5855-5866. 
(23) Takezawa, Y.; Hu, L.; Nakama, T.; Shionoya, M. Sharp Switching of DNAzyme Activity through the Formation of a $\mathrm{Cu}(\mathrm{II})$-Mediated Carboxyimidazole Base Pair. Angew. Chem. Int. Ed. 2020, 10.1002/anie.202009579.

(24) Takezawa, Y.; Shionoya, M. Metal-mediated DNA base pairing: alternatives to hydrogen-bonded Watson-Crick base pairs. Acc. Chem. Res. 2012, 45, 2066-2076.

(25) Wang, F.; Liu, X.; Willner, I. DNA switches: from principles to applications. Angew. Chem. Int. Ed. 2015, 54, 1098-1129.

(26) Wang, S. R.; Wang, J. Q.; Fu, B. S.; Chen, K.; Xiong, W.; Wei, L.; Qing, G.; Tian, T.; Zhou, X. Supramolecular Coordination-Directed Reversible Regulation of Protein Activities at Epigenetic DNA Marks. J. Am. Chem. Soc. 2018, 140, 15842-15849.

(27) Beharry, A. A.; Woolley, G. A. Azobenzene photoswitches for biomolecules. Chem. Soc. Rev. 2011, 40, 4422-4437.

(28) Kamiya, Y.; Asanuma, H. Light-driven DNA nanomachine with a photoresponsive molecular engine. Acc. Chem. Res. 2014, 47, 1663-1672.

(29) Liu, Q.; Deiters, A. Optochemical control of deoxyoligonucleotide function via a nucleobase-caging approach. Acc. Chem. Res. 2014, 47, 45-55.

(30) Lubbe, A. S.; Liu, Q.; Smith, S. J.; de Vries, J. W.; Kistemaker, J. C. M.; de Vries, A. H.; Faustino, I.; Meng, Z.; Szymanski, W.; Herrmann, A.; Feringa, B. L. Photoswitching of DNA Hybridization Using a Molecular Motor. J. Am. Chem. Soc. 2018, 140, 5069-5076.

(31) Lubbe, A. S.; Szymanski, W.; Feringa, B. L. Recent developments in reversible photoregulation of oligonucleotide structure and function. Chem. Soc. Rev. 2017, 46, 10521079.

(32) Szymanski, W.; Beierle, J. M.; Kistemaker, H. A.; Velema, W. A.; Feringa, B. L. Reversible photocontrol of biological systems by the incorporation of molecular photoswitches. Chem. Rev. 2013, 113, 6114-6178.

(33) Beaucage, S. L.; Caruthers, M. H. Deoxynucleoside phosphoramidites-A new class of key intermediates for deoxypolynucleotide synthesis. Tetrahedron Lett. 1981, 22, 1859-1862.

(34) Beaucage, S. L.; Lyer, R. P. Advances in the Synthesis of Oligonucleotides by the Phosphoramidite Approach. Tetrahedron Lett. 1992, 48, 2223-2311.

(35) Matteucci, M. D.; Caruthers, M. H. Synthesis of deoxyoligonucleotides on a polymer support. J. Am. Chem. Soc. 1981, 103, 3185-3191.

(36) McBride, L. J.; Caruthers, M. H. An investigation of several deoxynucleoside phosphoramidites useful for synthesizing deoxyoligonucleotides. Tetrahedron Lett. 1983, 24, 245-248.

(37) Chen, Y.; Ke, G.; Ma, Y.; Zhu, Z.; Liu, M.; Liu, Y.; Yan, H.; Yang, C. J. A Synthetic Light-Driven Substrate Channeling System for Precise Regulation of Enzyme Cascade Activity Based on DNA Origami. J. Am. Chem. Soc. 2018, 140, 8990-8996.

(38) Zhang, L.; Linden, G.; Vazquez, O. In search of visible-light photoresponsive peptide nucleic acids (PNAs) for reversible control of DNA hybridization. Beilstein J. Org. Chem. 2019, 15, 2500-2508.

(39) Sarter, C.; Dey, S.; Jaschke, A. Photoswitchable Oligonucleotides Containing Different Diarylethene-Modified Nucleotides. ACS Omega 2019, 4, 12125-12129.

(40) Skugor, M.; Valero, J.; Murayama, K.; Centola, M.; Asanuma, H.; Famulok, M. Orthogonally Photocontrolled Non-Autonomous DNA Walker. Angew. Chem. Int. Ed. 2019, $58,6948-6951$.

(41) Velema, W. A.; Kietrys, A. M.; Kool, E. T. RNA Control by Photoreversible Acylation. J. Am. Chem. Soc. 2018, 140, 3491-3495.

(42) Zhou, W.; Brown, W.; Bardhan, A.; Delaney, M.; Ilk, A. S.; Rauen, R. R.; Kahn, S. I.; Tsang, M.; Deiters, A. Spatiotemporal Control of CRISPR/Cas9 Function in Cells and Zebrafish using Light-Activated Guide RNA. Angew. Chem. Int. Ed. 2020, 59, 8998-9003.

(43) Matsumura, Y.; Ananthaswamy, H. N. Toxic effects of ultraviolet radiation on the skin. Toxicol. Appl. Pharmacol. 2004, 195, 298-308.

(44) Narayanan, D. L.; Saladi, R. N.; Fox, J. L. Ultraviolet radiation and skin cancer. Int. J. Dermatol. 2010, 49, 978-986. 
(45) Aprahamian, I. Hydrazone switches and things in between. Chem. Commun. 2017, 53, 6674-6684.

(46) Harris, J. D.; Moran, M. J.; Aprahamian, I. New molecular switch architectures. Proc. Natl. Acad. Sci. U. S. A. 2018, 115, 9414-9422.

(47) Li, Q.; Qian, H.; Shao, B.; Hughes, R. P.; Aprahamian, I. Building Strain with Large Macrocycles and Using It To Tune the Thermal Half-Lives of Hydrazone Photochromes. $J$. Am. Chem. Soc. 2018, 140, 11829-11835.

(48) Moran, M. J.; Magrini, M.; Walba, D. M.; Aprahamian, I. Driving a Liquid Crystal Phase Transition Using a Photochromic Hydrazone. J. Am. Chem. Soc. 2018, 140, 13623-13627.

(49) Qian, H.; Pramanik, S.; Aprahamian, I. Photochromic Hydrazone Switches with Extremely Long Thermal Half-Lives. J. Am. Chem. Soc. 2017, 139, 9140-9143.

(50) Shao, B.; Baroncini, M.; Qian, H.; Bussotti, L.; Di Donato, M.; Credi, A.; Aprahamian, I. Solution and Solid-State Emission Toggling of a Photochromic Hydrazone. J. Am. Chem. Soc. 2018, 140, 12323-12327.

(51) Shao, B.; Stankewitz, N.; Morris, J. A.; Liptak, M. D.; Aprahamian, I. White-light emission from a structurally simple hydrazone. Chem. Commun. 2019, 55, 9551-9554.

(52) Su, X.; Aprahamian, I. Hydrazone-based switches, metallo-assemblies and sensors. Chem. Soc. Rev. 2014, 43, 1963-1981.

(53) van Dijken, D. J.; Kovaricek, P.; Ihrig, S. P.; Hecht, S. Acylhydrazones as Widely Tunable Photoswitches. J. Am. Chem. Soc. 2015, 137, 14982-14991.

(54) Guo, X.; Shao, B.; Zhou, S.; Aprahamian, I.; Chen, Z. Visualizing intracellular particles and precise control of drug release using an emissive hydrazone photochrome. Chem. Sci. 2020, 11, 3016-3021.

(55) Lehn, J. M. Perspectives in chemistry--aspects of adaptive chemistry and materials. Angew. Chem. Int. Ed. 2015, 54, 3276-3289.

(56) Ryabchun, A.; Li, Q.; Lancia, F.; Aprahamian, I.; Katsonis, N. Shape-Persistent Actuators from Hydrazone Photoswitches. J. Am. Chem. Soc. 2019, 141, 1196-1200.

(57) Shao, B.; Qian, H.; Li, Q.; Aprahamian, I. Structure Property Analysis of the Solution and Solid-State Properties of Bistable Photochromic Hydrazones. J. Am. Chem. Soc. 2019, 141, 8364-8371.

(58) Chaur, M. N.; Collado, D.; Lehn, J. M. Configurational and constitutional information storage: multiple dynamics in systems based on pyridyl and acyl hydrazones. Chemistry 2011, 17, 248-258.

(59) Chou, C.; Young, D. D.; Deiters, A. A light-activated DNA polymerase. Angew. Chem. Int. Ed. 2009, 48, 5950-5953.

(60) Piotto, M.; Saudek, V.; Sklenar, V. Gradient-tailored excitation for single-quantum NMR spectroscopy of aqueous solutions. J. Biomol. NMR 1992, 2, 661-665.

(61) Marx, A.; Detmer, I.; Gaster, J.; Summerer, D. Probing DNA Polymerase Function with Synthetic Nucleotides. Synthesis 2004, 1, 1-14.

(62) Samanta, B.; Seikowski, J.; Hobartner, C. Fluorogenic Labeling of 5-Formylpyrimidine Nucleotides in DNA and RNA. Angew. Chem. Int. Ed. 2016, 55, 1912-1916.

(63) Young, D. D.; Edwards, W. F.; Lusic, H.; Lively, M. O.; Deiters, A. Light-triggered polymerase chain reaction. Chem. Commun. 2008, 462-464.

(64) Kiefer, J. R.; Mao, C.; Hansen, C. J.; Basehore, S. L.; Hogrefe, H. H.; Braman, J. C.; Beese, L. S. Crystal structure of a thermostable Bacillus DNA polymerase I large fragment at 2.1 A resolution. Structure 1997, 5, 95-108.

(65) Shi, C.; Shen, X.; Niu, S.; Ma, C. Innate Reverse Transcriptase Activity of DNA Polymerase for Isothermal RNA Direct Detection. J. Am. Chem. Soc. 2015, 137, 13804-13806. (66) Ollis, D. L.; Brick, P.; Hamlin, R.; Xuong, N. G.; Steitz, T. A. Structure of large fragment of Escherichia coli DNA polymerase I complexed with dTMP. Nature 1985, 313, 762-766.

(67) Zheng, W.; Brooks, B. R.; Doniach, S.; Thirumalai, D. Network of dynamically important residues in the open/closed transition in polymerases is strongly conserved. Structure 2005, 13, 565-577. 